\title{
Assessment of Undiscovered Oil and Gas Resources of the Cretaceous-Tertiary Composite Total Petroleum System, Taranaki Basin Assessment Unit, New Zealand
}

The Cretaceous-Tertiary Composite Total Petroleum System coincident Taranaki Basin Assessment Unit was recently assessed for undiscovered technically recoverable oil, natural gas, and natural gas liquids resources as part of the U.S. Geological Survey (USGS) World Energy Resources Project, World Oil and Gas Assessment. Using a geology-based assessment methodology, the USGS estimated mean volumes of 487 million barrels of oil, 9.8 trillion cubic feet of gas, and 408 million barrels of natural gas liquids.

\section{Introduction}

The U.S. Geological Survey (USGS) World Energy Resources Project conducts assessments of the potential for undiscovered, technically recoverable oil and natural gas resources of the world, exclusive of the United States. As a part of this program, the USGS recently completed an assessment of the conventional undiscovered resources of the Cretaceous-Tertiary Composite Total Petroleum System (TPS), Taranaki Basin Assessment Unit (AU), onshore and offshore New Zealand (fig. 1). The TPS and AU boundaries are coincident and will be referred to as the AU. Potential unconventional resources such as shale oil and coalbed methane were identified but not assessed. This assessment was based on data from oil and gas exploration wells, production data, and published geologic, seismic, and geochemical reports.

\section{The Cretaceous-Tertiary Composite Total Petroleum System and Taranaki Basin Assessment Unit}

The Cretaceous-Tertiary Composite TPS and Taranaki Basin AU include an area of approximately 153,000 square kilometers $\left(\mathrm{km}^{2}\right)$. The TPS and $\mathrm{AU}$ boundaries are coincident and will be referred to as the AU. The offshore portion of the AU makes up approximately 80 percent of the total area. Water depths range from 0 to 1,500 meters. The AU includes Cretaceous and Tertiary rocks in all or part of the Taranaki, Wanganui, and Deep-Water Taranaki Basins (fig. 1).

Situated on the Australian tectonic plate, the AU consists of an onshore and offshore eastern graben complex and an offshore western stable platform. The graben complex and stable platform developed during Jurassic and Late CretaceousPaleogene rifting events between Australia and New Zealand that created a rift sag basin and the Tasman Sea. The

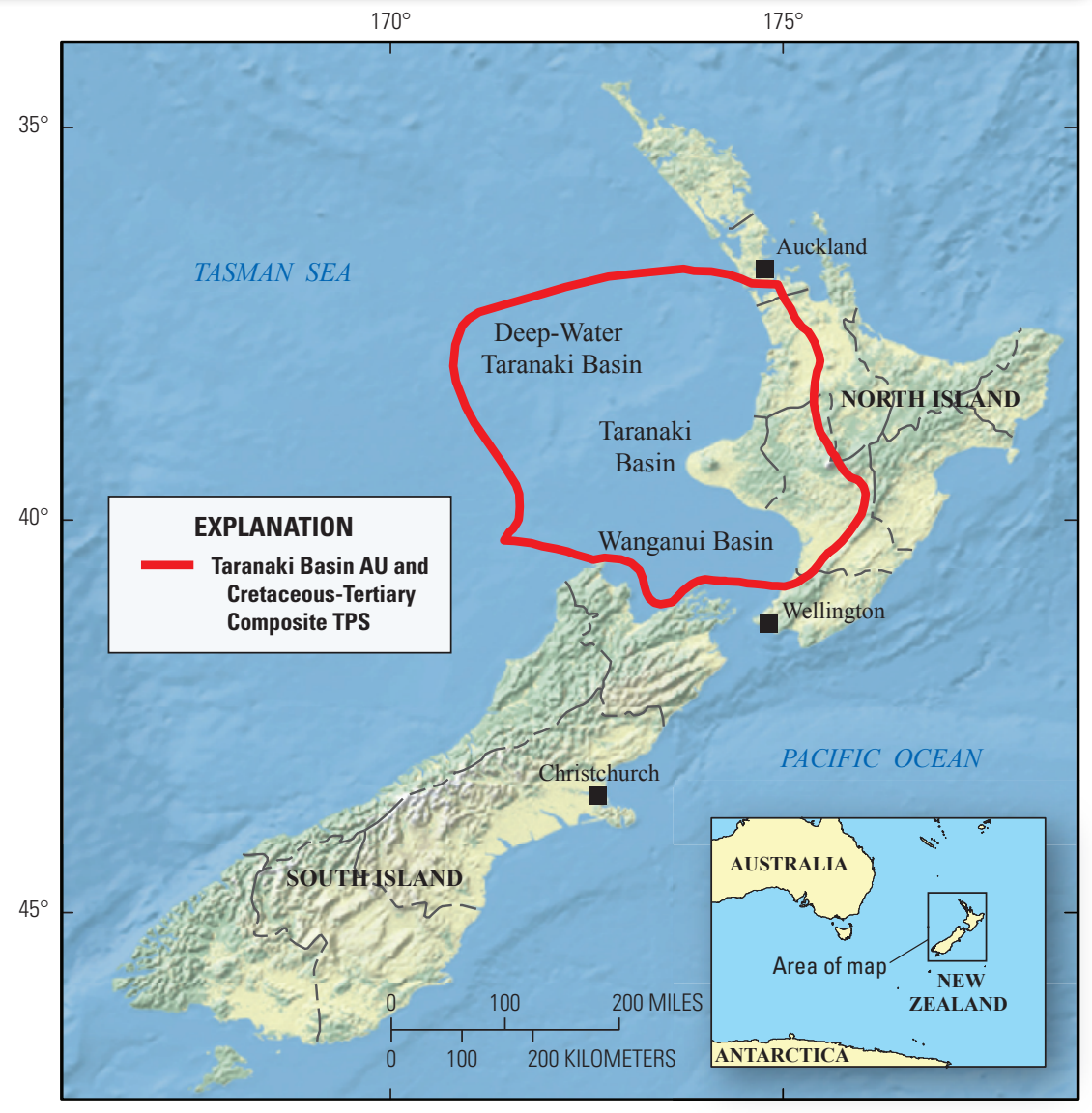

Figure 1. Assessed area of New Zealand was defined as a single composite assessment unit (AU), Taranaki Basin AU 30310101 (outlined in red). TPS, total petroleum system.

Late Cretaceous-Paleogene rifting was followed, from 35 to 24 million years ago $(\mathrm{Ma})$, by a relatively continuous period of regional compression and initiation of subduction of the Pacific plate. Collision of the Australian and Pacific plates resulted in the Australian plate overriding the Pacific plate on North Island and the Pacific plate overriding the Australian plate on South Island creating a plate inversion zone between the North and South Islands. The southernmost portion of the AU, between 
the North and South Islands, is part of the plate inversion zone. Back-arc extension related to subduction started approximately $4 \mathrm{Ma}$ and continues today.

The source rocks include Cretaceous and Paleogene marine and lacustrine shales and mudstones and Cretaceous and possibly Jurassic coals. Oil and gas generation occurred as early as Late Cretaceous in the deep-water part of the AU (Deep-Water Taranaki Basin) (Uruski and Warburton, 2010). Due to a varied burial history, generation has continued intermittently in different parts of the AU throughout the Cenozoic and is ongoing today in parts of the AU. The Taranaki Basin is filled with as much as $9 \mathrm{~km}$ of sediments. Maximum burial depth occurred during late Miocene in much of the basin. Migration is primarily along fault zones and into adjacent reservoirs.

Cretaceous and Tertiary reservoir rocks and potential reservoir rocks include turbidites, carbonates, alluvial sandstones, and volcaniclastics. Traps are primarily structural. Collisionrelated late Tertiary tectonics created three primary structural trap types - faulted anticlines, overthrusts, and tilted fault blocks (Crown Minerals, 2011). Seals are primarily shales and mudstones. Production is mainly from sandstones of the Eocene Kapuni Group and Oligocene Otaraoa Formation. There are eight discovered oil accumulations and twelve gas accumulations with a grown size (maximum expected volume of production) greater than the 5 million barrels of oil equivalent minimum assessed size (IHS Energy, 2010). Two fields, Kapuni and Maui, presently account for over 80 percent of New Zealand's gas production and condensate (Crown Minerals, 2011). The Kapuni and Maui fields formed in faulted anticline traps.

\section{Resource Summary}

The Cretaceous-Tertiary Composite TPS, Taranaki Basin AU, was assessed for undiscovered technically recoverable oil, natural gas, and natural gas liquids resources. Using a geologybased assessment methodology (U.S. Geological Survey World Energy Assessment Team, 2000), the USGS estimated mean volumes of 487 million barrels of oil, 9.8 trillion cubic feet of gas, and 408 million barrels of natural gas liquids.

\section{References Cited}

Crown Minerals, 2011, New Zealand petroleum basins: New Zealand, Crown Mineral Estate, Ministry of Economic Development, accessed January 07, 2013, at $h t t p: / / w w w$. nzpam.govt.nz/cms.

IHS Energy, 2010, International petroleum exploration and production database [current through December 2010]: Available from IHS-Energy, 15 Inverness Way East, Englewood, CO 80112.

Uruski, C.I., and Warburton, J., 2010, Seismic evidence for active petroleum systems and charge history; PEP 38451 deep-water Taranaki Basin, in 2010 New Zealand petroleum conference: Conference Proceedings, Crown Minerals, Ministry of Economic Development, Wellington, New Zealand, 1 CD ROM.

U.S. Geological Survey World Energy Assessment Team, 2000, U.S. Geological Survey world petroleum assessment 2000Description and results: U.S. Geological Survey Digital Data Series DDS-60, 4 CD ROMS.

Table 1. Taranaki Basin Assessment Unit assessment results.

[MMBO, million barrels of oil; BCFG, billion cubic feet of gas; MMBNGL, million barrels of natural gas liquids. Results shown are fully risked estimates. For gas fields, all liquids are included under the NGL (natural gas liquids) category. Undiscovered gas resources are the sum of nonassociated and associated gas. F95 represents a 95-percent chance of at least the amount tabulated. Other fractiles are defined similarly. Fractiles are additive under the assumption of perfect positive correlation. Largest expected oil field size is in MMBO; largest expected gas field is in BCFG. Gray shading indicates not applicable].

\begin{tabular}{|c|c|c|c|c|c|c|c|c|c|c|c|c|c|c|}
\hline \multirow{3}{*}{$\begin{array}{l}\text { Total petroleum systems } \\
\text { (TPS) } \\
\text { and assessment units (AU) }\end{array}$} & \multirow{3}{*}{$\begin{array}{l}\text { Field } \\
\text { type }\end{array}$} & \multirow{3}{*}{$\begin{array}{l}\text { Largest } \\
\text { expected } \\
\text { mean } \\
\text { field size }\end{array}$} & \multicolumn{12}{|c|}{ Total undiscovered resources } \\
\hline & & & \multicolumn{4}{|c|}{ Oil (MMBO) } & \multicolumn{4}{|c|}{ Gas (BCFG) } & \multicolumn{4}{|c|}{ NGL (MMBNGL) } \\
\hline & & & F95 & F50 & F5 & Mean & F95 & F50 & F5 & Mean & F95 & F50 & F5 & Mean \\
\hline \multicolumn{15}{|c|}{ Cretaceous-Tertiary Composite TPS } \\
\hline \multirow{2}{*}{ Taranaki Basin AU } & Oil & 53 & 269 & 464 & 781 & 487 & 310 & 546 & 925 & 572 & 6 & 12 & 20 & 12 \\
\hline & Gas & 1,011 & & & & & 4,895 & 8,797 & 15,036 & 9,225 & 209 & 377 & 646 & 396 \\
\hline $\begin{array}{l}\text { Total conventional } \\
\text { resources }\end{array}$ & & & 269 & 464 & 781 & 487 & 5,205 & 9,343 & 15,961 & 9,797 & 215 & 389 & 666 & 408 \\
\hline
\end{tabular}

\section{For Additional Information}

Assessment results are available at the USGS Central Energy Resources Science Center Web site: http://energy.usgs.gov/OilGas.aspx or contact Craig J. Wandrey, assessing geologist (cwandrey@usgs.gov).

\section{Taranaki Basin Assessment Team}

Craig J. Wandrey, Christopher J. Schenk, Timothy R. Klett, Michael E. Brownfield, Ronald R. Charpentier, Troy A. Cook, Richard M. Pollastro, and Marilyn E. Tennyson. 